\title{
Effects of transforming growth factor- $\beta$ on mammary remodeling during the dry period of dairy cows
}

\author{
L. D. De Vries, ${ }^{*}$ T. Casey,,${ }^{1}$ H. Dover, ${ }^{*}$ M. J. VandeHaar, ${ }^{*}$ and K. Plaut $†$ \\ ${ }^{*}$ Department of Animal Science, Michigan State University, East Lansing 48824-1225 \\ †Department of Animal Science, Purdue University, West Lafayette, IN 47907
}

\begin{abstract}
Mammary remodeling in dairy cows involves coordinated changes in stromal and epithelial tissue. Tissue remodeling is characterized by changes in cell proliferation, activation of fibroblasts into myofibroblasts, and changes in extracellular matrix content. Transforming growth factor $\beta-1$ (TGF- $\beta 1$ ) increases differentiation of fibroblasts to myofibroblasts, regulates expression of extracellular matrix proteins and proteases, and has cell-type dependent effects on proliferation. The objective of this study was to determine whether TGF- $\beta 1$ treatment of mammary tissue from cows in late lactation and the dry period affects cell proliferation, expression of matrix metalloproteinase-3 (MMP-3) and fibronectin $(\mathrm{FN})$, and the differentiation of fibroblasts into myofibroblasts that express smooth muscle $\alpha$ actin (SMA). Tissue was biopsied from 7 Holstein cows at 4 time points: late lactation, 1 wk after dry-off, 3 wk before expected calving, and $1 \mathrm{wk}$ before expected calving. Explants of biopsied tissue were incubated for $2 \mathrm{~h}$ in Waymouth's medium containing insulin, hydrocortisone, and 0 or $5 \mathrm{ng}$ of TGF- $\beta 1 / \mathrm{mL}$; a subset of cultures was also incubated with bromodeoxyuridine to measure epithelial and stromal cell proliferation. Tissues were fixed, embedded in paraffin, sectioned, and stained by immunohistochemistry. Stage at biopsy had an overall effect on rate of epithelial and stromal cell proliferation, and TGF- $\beta 1$ treatment increased rate of bromodeoxyuridine incorporation more than 2-fold in both cell types at 1 wk after dry-off. The number of fibroblasts expressing SMA was 19\% higher in the intralobular stroma at $1 \mathrm{wk}$ after dry-off compared with that at 1 wk before expected calving, and the percentage of activated fibroblasts tended to be higher in tissue incubated with TGF- $\beta 1$. Biopsy stage had an overall effect on percentage area of epithelium expressing FN and MMP-3. Incubation with TGF- $\beta 1$ had no effect on percentage intralobular stroma area express-
\end{abstract}

Received May 31, 2011.

Accepted August 27, 2011.

${ }^{1}$ Corresponding author: theresa-casey@purdue.edu ing FN or MMP-3. Effects of TGF- $\beta 1$ treatment were most apparent at $1 \mathrm{wk}$ after dry-off, indicating that the first week of dry period may be an ideal target for testing effects in vivo.

Key words: extracellular matrix, mammary, myofibroblast, transforming growth factor- $\beta$

\section{INTRODUCTION}

Although mammary remodeling during the dry period appears to be important for the subsequent lactation, it is unclear what happens during this process and what the optimal period is to maximize lifetime milk production. Interest exists in developing methods to shorten the dry period to reduce the environmental impact per unit of milk produced and to increase the profitability of dairy production (Rastani et al., 2005).

During the dry period, the mammary gland actively remodels in 2 main phases: involution after cessation of milk removal followed by a phase of redevelopment or mammogenesis before parturition (Hurley, 1989). The dry period is important for renewal and replacement of senescent epithelial cells, particularly during mammogenesis before parturition (Capuco et al., 1997; Sorensen et al., 2006; Annen et al., 2007) as well as changes in intralobular stromal composition (De Vries et al., 2010). Composition of the stroma was shown to be important to epithelial cell fate in rodent models (Silberstein et al., 1992; Farrelly et al., 1999). In bovine mammary epithelial cell culture systems, composition of the extracellular matrix (ECM) was shown to regulate mammary progenitor cell differentiation into a secretory phenotype (Holland et al., 2007). Thus, alterations of stromal composition may provide a means of manipulating dry period length.

Transforming growth factor-betas (TGF- $\beta$ ) comprise a super-family of proteins that includes TGF- $\beta 1$, $\beta 2$, and $\beta 3$ as well as activins and inhibins (Kingsley, 1994). Transforming growth factor- $\beta 1$ regulates mammary development, and its expression is greatest during periods of tissue remodeling (for review, see Plaut et al., 2003). The role of TGF- $\beta 1$ has been studied primarily during mammary development and lactation in rodents, with varying results depending on timing and 
location of expression. Exogenous implants of TGF- $\beta 1$ in prepubertal murine mammary glands inhibited epithelial cell proliferation and stimulated synthesis of the ECM surrounding ducts (Silberstein et al., 1990). Musters et al. (2004) observed an increase in proliferation of both epithelial and stromal cells in heifers. Studies on transgenic overexpression of TGF- $\beta 1$ and in TGF- $\beta$ receptor II knockout mice have resulted in both lactation defects and normal lactation (Jhappan et al., 1993; Pierce et al., 1993; Joseph et al., 1999; Gorska et al., 2003). To date, no research has focused on the dry period. In cows, the dry period is a critical period when active remodeling in the mammary gland occurs, thus it is likely to be influenced by TGF- $\beta 1$.

Transforming growth factor- $\beta 1$ alters stromal composition in part by increasing the differentiation of stromal fibroblasts into active myofibroblasts, which in turn produce ECM proteins and proteases. The myofibroblast phenotype is associated with the contractile protein smooth muscle $\alpha$-actin (SMA) and increased synthesis of ECM proteins relative to fibroblasts (Petrov et al., 2002). Expression of SMA in myofibroblasts likely functions to alter ECM organization and aid in cell motility (Grinnell, 1994). Incubation of human mammary fibroblasts with $5 \mathrm{ng} / \mathrm{mL}$ of TGF- $\beta 1$ for $7 \mathrm{~d}$ increased the percentage of myofibroblasts from 7.5 to 45.3\% (Desmoulière et al., 1993). Transforming growth factor- $\beta 1$-induced differentiation of myofibroblasts may be important to production of ECM proteins in the intralobular stroma during tissue remodeling. Collagen synthesis increased in cultures with TGF- $\beta 1$, concomitant with an increase in myofibroblasts (Petrov et al., 2002). Therefore, TGF- $\beta 1$ may influence stromal composition, which in turn may distinctly affect periods of mammary remodeling, involution (i.e., the first week after dry-off), and mammogenesis (i.e., approximately the third week prepartum) during the dry period.

In addition to synthesizing ECM proteins, stromal fibroblasts and myofibroblasts produce proteases, including matrix metalloproteinases (MMP), which are involved in mammary remodeling (Dickson and Warburton, 1992; Noel and Foidart, 1998). The balance of MMP and their inhibitors during involution coordinates the degradation of the basement membrane and other ECM and contributes to alveolar regression during murine mammary involution (Talhouk et al., 1992). Furthermore, Simian et al. (2001) demonstrated that MMP-3 is necessary in vitro for ductal branching of mouse mammary epithelial cells.

The effects of TGF- $\beta 1$ on bovine mammary tissue during the dry period have not been investigated. Based on the role of TGF- $\beta 1$ in mammary development and tissue remodeling in mice and heifers, TGF- $\beta 1$ is likely an important mediator of mammary remodeling in the dry period. We hypothesized that exogenous TGF- $\beta 1$ would increase proliferation of myofibroblasts and stimulate mammary remodeling through increased production of MMP-3 and fibronectin. Furthermore, we expected that the effect of TGF- $\beta 1$ would be greater after the 1 wk dry and 3 wk prepartum time points, corresponding to active involution and mammogenesis, respectively, compared with that in late lactation and at $1 \mathrm{wk}$ prepartum.

\section{MATERIALS AND METHODS}

\section{Animals}

All animal handling and surgical procedures were performed humanely under the approval of the Michigan State University All University Committee on Animal Use and Care. Biopsied mammary tissue was obtained from 7 Holstein cows (3 multiparous, 4 primiparous) impregnated between 90 and 105 DIM from the Michigan State University Dairy Cattle Teaching and Research Center to study the effects of TGF- $\beta 1$ during the dry period. Cows were dried off at $310 \pm$ 12 DIM (mean \pm SD) and had an average dry period length of $55 \pm 5 \mathrm{~d}$ (mean days dry $\pm \mathrm{SD}$ ).

\section{Experimental Design}

Multiple biopsies were obtained from 7 cows in a split-plot design, where the main plot was cow and the subplot was the effect of TGF- $\beta 1$ on tissue biopsied from separate quarters of the mammary gland at 4 time points from late lactation through 1 wk before expected calving date as described previously (De Vries et al., 2010). Each quarter was only sampled once so that a previous biopsy would not influence subsequent biopsies. The quarters were assigned randomly and biopsied at late lactation (LL), 1 wk dry (1WD), 3 wk before expected calving date (3BEC), and $1 \mathrm{wk}$ before expected calving date (1BEC). Biopsied tissue sections from each sample were assigned to incubation treatments with 0 or $5 \mathrm{ng}$ of TGF- $\beta 1 / \mathrm{mL}$.

\section{Biopsy Procedure}

Biopsies were obtained using the method described by Farr et al. (1996) with several modifications. In brief, cows were restrained and sedated with an intramuscular injection of xylazine hydrochloride (Rompun, 35-45 $\mu \mathrm{g} / \mathrm{kg}$ of BW, Bayer Animal Health, Shawnee, KS). The biopsy site was shaved and washed with iodine, surgical scrub (Betadine Surgical Scrub, PurduePharma, Stamford, CT), and $70 \%$ ethanol. Approximately $1 \mathrm{~g}$ of tissue was collected using a stainless steel, retractable 
biopsy tool (AgResearch, Hamilton, New Zealand). The incision area was closed with surgical staples and Michel clips. A teat cannula was inserted into lactating quarters immediately after biopsy to drain accumulated blood and removed after approximately $5 \mathrm{~min}$. Quarters were hand-milked twice daily after biopsy to remove clots until the milk was free of visible blood.

\section{Tissue Processing}

Biopsied tissue was immediately placed in sterilized (using a $0.2-\mu \mathrm{m}$ filter), cold medium (Waymouth's Media $752 / 1$, Sigma, St Louis, MO), with $50 \mu \mathrm{g}$ of gentamicin per $\mathrm{mL}$ (Invitrogen, Carlsbad, CA) and $100 \mathrm{U}$ of penicillin and $100 \mu \mathrm{g}$ of streptomycin per $\mathrm{mL}$ (Sigma). Tissue was washed 3 times in PBS containing $100 \mathrm{U}$ of penicillin and $100 \mu \mathrm{g}$ of streptomycin per $\mathrm{mL}$, and $1.5 \mu \mathrm{g}$ of amphotericin B per $\mathrm{mL}$ (Invitrogen) and cut into $0.5-\mathrm{cm}^{3}$ explants. Approximately 10 explants were placed on siliconized lens paper and cultured in a humidified chamber $\left(5 \% \mathrm{CO}_{2}, 50 \% \mathrm{O}_{2}\right)$ at $37^{\circ} \mathrm{C}$ for $2 \mathrm{~h}$ in Waymouth's medium supplemented with $5 \mu \mathrm{g} / \mathrm{mL}$ insulin (Sigma), $0.1 \mu \mathrm{g} / \mathrm{mL}$ hydrocortisone (Sigma), and 0 or $5 \mathrm{ng} / \mathrm{mL}$ TGF- $\beta 1$ (240-B, R\&D Systems, Minneapolis, MN) in duplicate $35-\mathrm{mm}$ dishes. At each time point, one additional sample was cultured in 50 $\mu M$ 5-bromo 2-deoxyuridine (BrdU, Sigma) to obtain an index of proliferating cells. After culture, tissue was placed in formalin for $24 \mathrm{~h}$, transferred to $60 \%$ ethanol, embedded in paraffin, cut into $5-\mu \mathrm{m}$ tissue sections, and placed on silanized slides. One hematoxylin and eosin stained slide for each paraffin block was obtained for a general histological examination (Figure 1).

\section{Immunohistochemistry}

Biopsied tissue sections were stained in a set consisting of tissues treated with 0 and $5 \mathrm{ng}$ of TGF- $\beta 1 / \mathrm{mL}$ for all biopsies of a cow, a positive control slide, and a negative control slide where the primary antibody was substituted with PBS. A broad-spectrum streptavidin-peroxidase Histostain-kit (Zymed Laboratories Inc., San Francisco, CA) was used according to the manufacturer's directions. The primary antibodies used were mouse monoclonal anti-smooth muscle $\alpha$-actin at 1:10,000 applied for $45 \mathrm{~min}$ (A2547, Sigma), mouse monoclonal anti-fibronectin clone IST-3 at 1:10,000 applied for $1 \mathrm{~h}$ (F0791, Sigma), and rabbit polyclonal anti-MMP-3 at a 1:200 dilution applied for $45 \mathrm{~min}$ (3523R-100, Biovision Inc., Mountainview, CA). The Zymed BrdU Staining Kit (Invitrogen) was used to detect BrdU incorporation in cells.

\section{Photomicrograph Analysis}

Five photomicrograph images were captured with a Nikon Eclipse 50i light microscope (Nikon Instruments Inc., Melville, NY) at $200 \times$ and analyzed using Image Pro Plus 5.1 (Media Cybernetics, Bethesda, MD) analysis software. Percentage area of protein expression (3,3'-diaminobenzidine staining) of fibronectin (FN) and MMP-3 was evaluated separately in epithelial and stromal tissues using Image Pro Plus. The area of interest tool was used to select epithelial or stromal tissue. The basement membrane was included as part of the epithelial tissue when selecting the area of interest. The count/size tool was used to measure per area (object/ total area selected) stained by immunohistochemistry (De Vries et al., 2010). Data were expressed as mean percentage of tissue area expressing protein \pm standard error of the mean.

To determine the effect of treatment on activation of fibroblasts, fibroblasts expressing SMA were considered activated fibroblasts, or myofibroblasts. Stromal cells with phenotypic characteristics of fibroblasts (pale nuclei and not associated with blood vessels or other structures) were considered fibroblasts, although no specific antibody was used to distinguish them from other cell types. Myofibroblast differentiation was determined by counting the number of fibroblasts expressing SMA and the total number of fibroblasts in the intralobular stroma using the manual tag in Image Pro Plus. The results were presented as a percentage of fibroblasts expressing SMA (myofibroblasts) and as myofibroblasts per area of intralobular stroma (i.e., cells $/ \mathrm{mm}^{2}$ ).

To determine the proliferating index of cells, 4 classes of cells were counted in tissues incubated with BrdU: proliferating epithelial (labeled with BrdU), nonproliferating epithelial, proliferating stromal (labeled with BrdU), and nonproliferating stromal using Image Pro Plus software by manually tagging stained and unstained epithelial and stromal cells in the section. Data were expressed as mean percentage proliferating \pm standard error of the mean.

\section{Statistical Analysis}

Analysis of variance of the data was conducted with the MIXED procedure in SAS v.9.1.3 software (SAS Institute Inc., Cary, NC) using the following model:

$$
\mathrm{Y}_{\mathrm{ijk}}=\mu+\mathrm{C}_{\mathrm{i}}+\mathrm{T}_{\mathrm{j}}+\mathrm{B}_{\mathrm{k}}+\mathrm{e}_{\mathrm{ijk}} \text {, }
$$

where $Y_{\mathrm{ijk}}=$ dependent variable, $\mu=$ overall mean, $\mathrm{C}$ $=$ random effect of cow ( $\mathrm{i}=1$ to 7 cows), $\mathrm{T}=$ fixed 


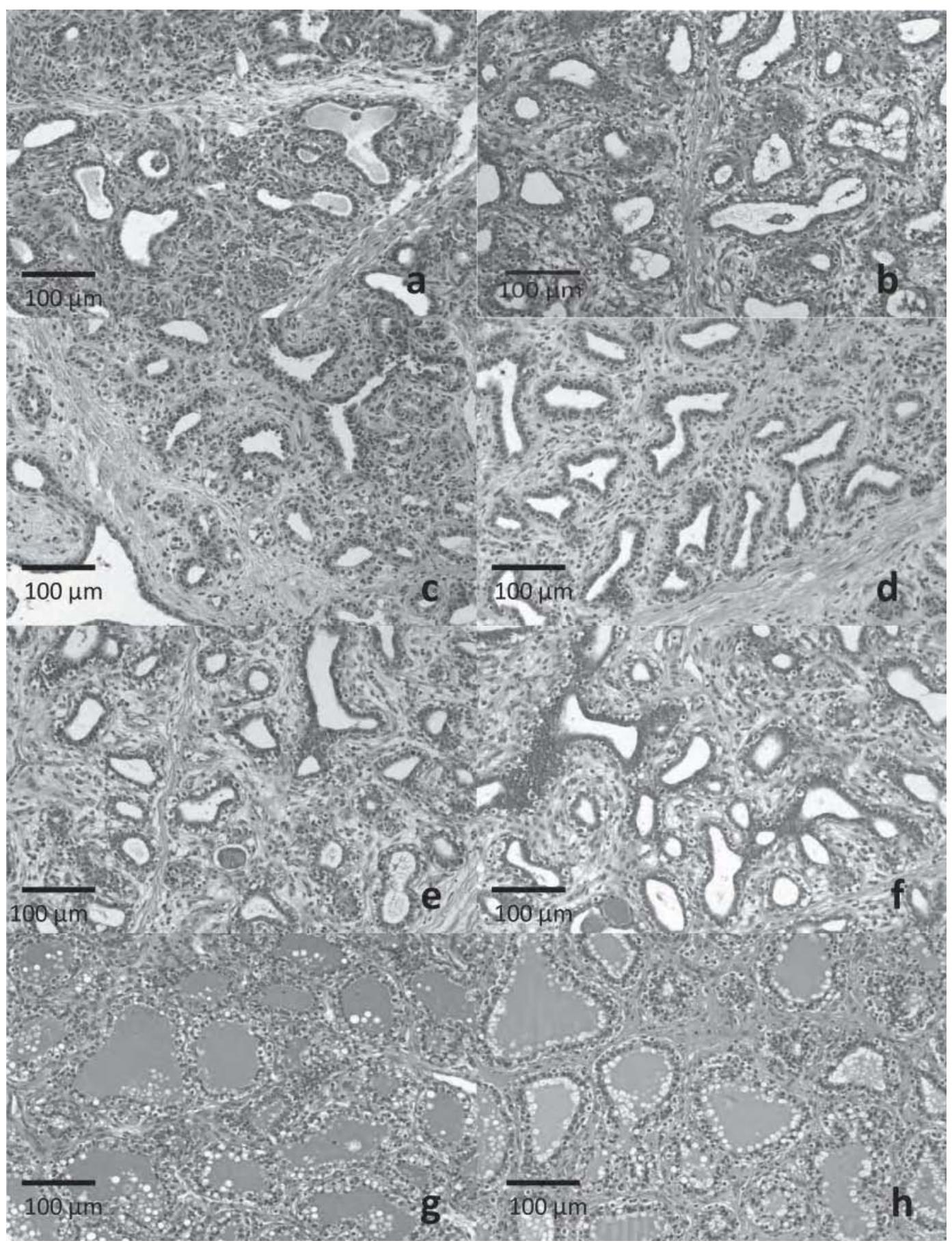

Figure 1. Hematoxylin and eosin staining $(200 \times)$ of mammary tissue incubated with and without transforming growth factor- $\beta 1$ (TGF- $\beta 1$ ). Images are of tissue incubated with $0 \mathrm{ng}$ of TGF- $\beta 1 / \mathrm{mL}(\mathrm{a}, \mathrm{c}, \mathrm{e}, \mathrm{g})$ or $5 \mathrm{ng}$ of TGF- $\beta 1 / \mathrm{mL}(\mathrm{b}, \mathrm{d}, \mathrm{f}, \mathrm{h})$. Tissue was obtained at late lactation (a, b), 1 wk after dry-off (c, d), 3 wk before expected calving date (e, f), or 1 wk before expected calving date ( $g$, h). Color version available in the online PDF.

effect of treatment $(\mathrm{j}=1$ to $2 ; 0$ or $5 \mathrm{ng}$ of TGF- $\beta 1 /$ $\mathrm{mL}), \mathrm{B}=$ fixed effect of stage at biopsy $(\mathrm{k}=1$ to $4 ; \mathrm{LL}$, $1 \mathrm{WD}, 3 \mathrm{BEC}, 1 \mathrm{BEC})$, and $\mathrm{e}_{\mathrm{ijk}}=$ residual error.

The effect of parity (primiparous or multiparous) and the interaction between biopsy and treatment were evaluated, but removed from the model when not declared significant $(P>0.1)$. Results were considered statistically significant at a probability of $\alpha<0.05$ and are presented as least squares means \pm standard error of the mean. 


\section{RESULTS}

\section{Histology and Proliferating Index of Epithelial and Stromal Cells}

Examination of sections stained with hematoxylin and eosin showed that mammary development at each stage of biopsy was similar to that in tissue not exposed to explant culture (De Vries et al., 2010), and no overt differences were found in tissue morphology between treatments (Figure 1). In total, 366,539 cells were counted to determine the proliferating index of epithelial and stromal cells, with an average of 3,500 epithelial cells and 3,100 stromal cells counted per cow and stage at biopsy for each treatment. Treatment with TGF- $\beta 1$ significantly increased $(P<0.05)$ proliferation rates of epithelial cells by 2.2 -fold and stromal cells by 2.6-fold in cultures of tissues obtained at 1WD (Figure $2)$. Stage at biopsy had an overall effect $(P<0.05)$ on stromal cell proliferation, with the mean BrdU-labeled index increasing from $0.21 \%$ in LL to $0.67 \%$ at $1 \mathrm{BEC}$ in control cultures (Figure 2A). The index of proliferating epithelial cells also showed an overall increase of more than 2.5-fold from LL and 1WD to 1BEC $(P<0.05)$ in the control cultures (Figure 2B).

\section{Fibroblasts and Myofibroblasts}

Positive staining for SMA was present in the myoepithelial cells, endothelial cells, and some fibroblastlike stromal cells (Figure 3). The percentage of myofibroblasts tended to be higher in tissue incubated with TGF- $\beta 1$ compared with the control $(P=0.06)$. Furthermore, the number of myofibroblasts per $\mathrm{mm}^{2}$ of intralobular stroma increased by $19 \%(P<0.05)$ in tissue explants incubated with TGF- $\beta 1$ compared with the control (Figure 4). Treatment with TGF- $\beta 1$ had no effect on the number or percentage of fibroblasts in the intralobular stroma (Table 1 and Figure 4).

\section{Expression of MMP-3 and Fibronectin}

Fibronectin staining was present in all tissue sections at all biopsy stages (Figure 3). A lighter intensity of FN staining was observed in the intralobular stroma compared with the interlobular stroma. An overall effect of stage at biopsy on percentage of epithelium expressing FN was observed $(P<0.05)$. In control cultures, mean percentage of epithelial area expressing $\mathrm{FN}$ in LL was significantly greater than that at $1 \mathrm{BEC}(P<0.05$; Figure 5a). Treatment with TGF- $\beta 1$ did not significantly affect percentage of epithelium expressing FN, and TGF- $\beta 1$ did not alter the percentage intralobular stromal area stained for FN at any biopsy stage (data not shown).
Staining for MMP-3 was also present at all stages; MMP-3 staining was darker in epithelial cells and in the interlobular stroma compared with the intralobular stroma. Stage at biopsy had an overall effect on percentage of epithelium expressing MMP-3 $(P<0.05)$. However, TGF- $\beta 1$ treatment had no effect on percentage intralobular stromal area stained for MMP-3 (data not shown).

\section{DISCUSSION}

We hypothesized that the roles of TGF- $\beta 1$ in mammary involution were to regulate ECM remodeling and stimulate turnover of cell populations. These roles are supported by in vitro and in vivo findings, which showed that addition of TGF- $\beta 1$ to epithelial cells stimulates synthesis of ECM proteins and inhibits epithelial cell growth (Silberstein and Daniel, 1987; Musters et al., 2004; Casey et al., 2007) and that the expression of TGF- $\beta 1$ mRNA increases in rodent and bovine mammary gland (both pregnant and nonpregnant) after the initiation of involution (Plath et al., 1997; Faure et al., 2000; Bierie et al., 2009).

We found that the rate of epithelial proliferation increased during the dry period from 1 wk dry to $1 \mathrm{wk}$ prepartum, which is in agreement with work of others (Capuco et al., 1997; Nørgaard et al., 2008). Treatment with TGF- $\beta 1$ significantly increased the rate of epithelial proliferation in mammary tissue from cows at $1 \mathrm{wk}$ dry. This observation was somewhat surprising in light of our hypothesis. In previous studies, we showed that $5 \mathrm{ng} / \mathrm{mL}$ TGF- $\beta 1$ inhibited mouse mammary epithelial cell growth, in part through arresting cells in $\mathrm{G}_{1} / \mathrm{G}_{0}$ (Casey et al., 2007). Exogenous TGF- $\beta 1$ implanted in mammary glands of prepubertal mice also inhibited epithelial cell proliferation in end buds (Silberstein and Daniel, 1987). However, when we implanted slowrelease TGF- $\beta 1$ pellets into pubertal heifer mammary glands, epithelial cell proliferation tended to increase (Musters et al., 2004). We believed this finding was due to stimulatory effects of TGF- $\beta 1$ on epithelial cell proliferation at lower concentrations. A dosage-dependent biphasic effect of TGF- $\beta 1$ on epithelial cell proliferation was demonstrated in organoid cultures of heifer mammary tissue (Ellis et al., 2000).

Similar to our previous report (De Vries et al., 2010), we found that the density of stromal fibroblasts changed throughout the dry period with the greatest density at 1WD (Table 1). In this study, the addition of BrdU to explant cultures showed that the percentage of stromal fibroblasts proliferating increased from 1WD to 1BEC, suggesting that the dry period is not only a time of epithelial cell renewal (Capuco et al., 1997), but also of stromal fibroblast renewal. 


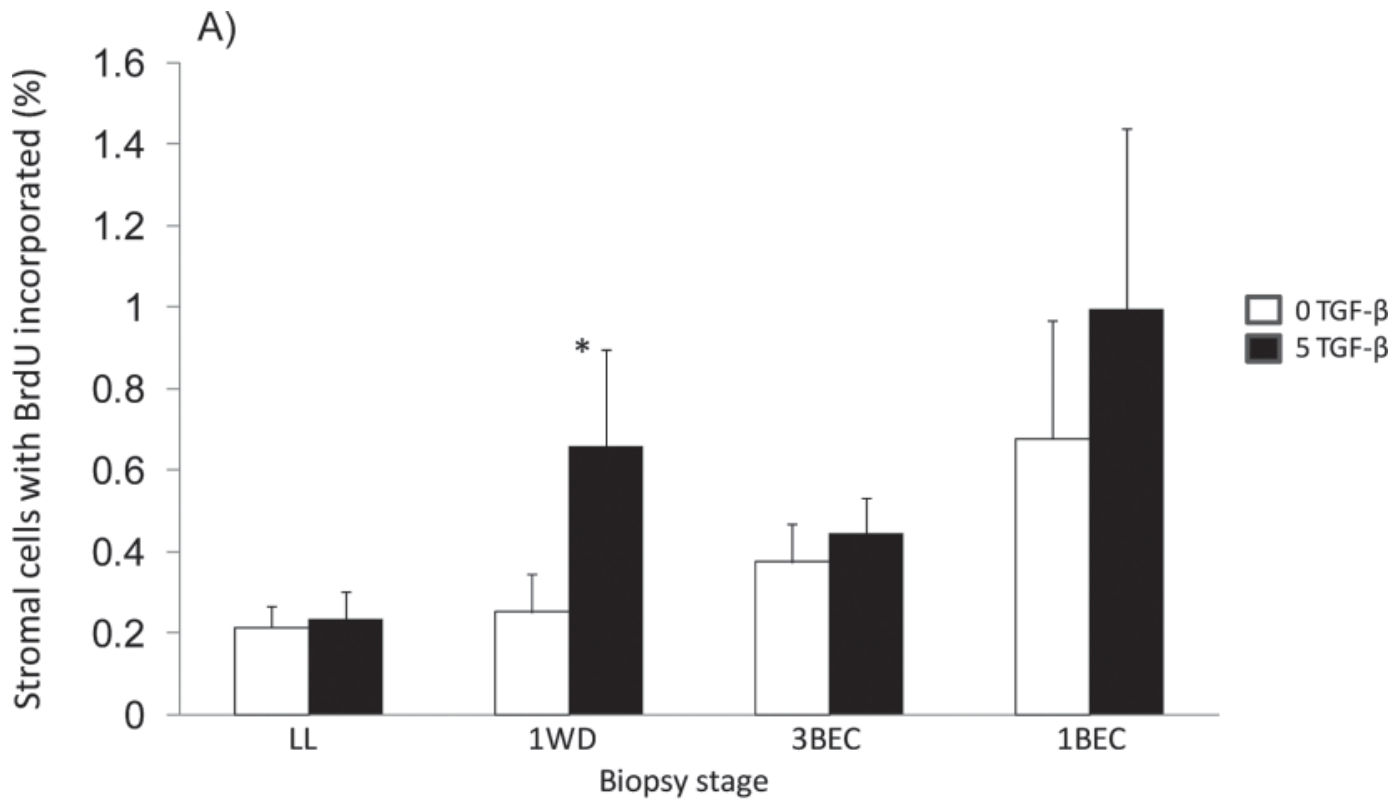

B)

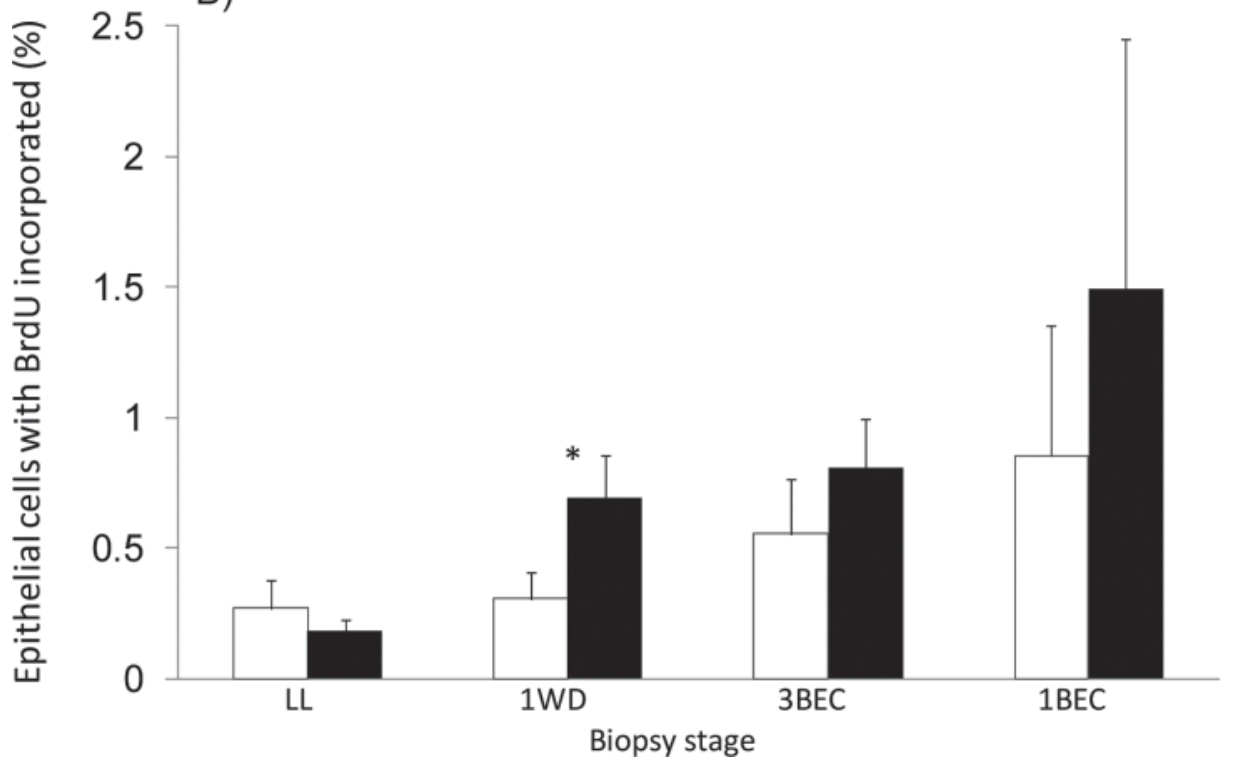

Figure 2. Effect of biopsy stage and transforming growth factor- $\beta 1$ (TGF- $\beta 1)$ treatment on (A) stromal cell proliferation $(*=$ overall effect of stage at $P<0.05)$ and $(\mathrm{B})$ epithelial cell proliferation $(*=$ significant TGF- $\beta 1$ effect at $P<0.05)$ in explant culture. Values are mean \pm SEM. $\mathrm{LL}=$ late lactation; $1 \mathrm{WD}=1 \mathrm{wk}$ dry; $3 \mathrm{BEC}=3 \mathrm{wk}$ before expected calving; and $1 \mathrm{BEC}=1 \mathrm{wk}$ before expected calving.

Although TGF- $\beta 1$ increased the percentage of fibroblast proliferation in tissue biopsied at $1 \mathrm{WD}$, it had no effect on the density of stromal fibroblasts (Figure 5A; Table 1). It is likely that a 2 -h incubation is sufficient to see changes in proliferation rate among existing fibroblasts but too short to detect differences in cell number. Measurable differences in cell number would likely require at least $24 \mathrm{~h}$ of culture. Treatment with TGF- $\beta 1$ increased the number of myofibroblasts, as measured by SMA expression, in the intralobular stroma by $19 \%(P<0.05)$. In addition, the percentage of myofibroblasts tended to be higher in the intralobular stroma of tissue treated with TGF- $\beta 1$ than in controls $(P=0.06)$. Because this short-term incubation with TGF- $\beta 1$ did not alter the total number of fibroblasts in the intralobular stroma (Table 1), it is likely that TGF- $\beta 1$ induced existing fibroblasts to differentiate into myofibroblasts during the dry period. These findings are consistent with our expected results and with other studies that found increased expression of SMA by fibroblast cells treated with TGF- $\beta 1$ in culture (Rønnov-Jessen and Petersen, 1993). 

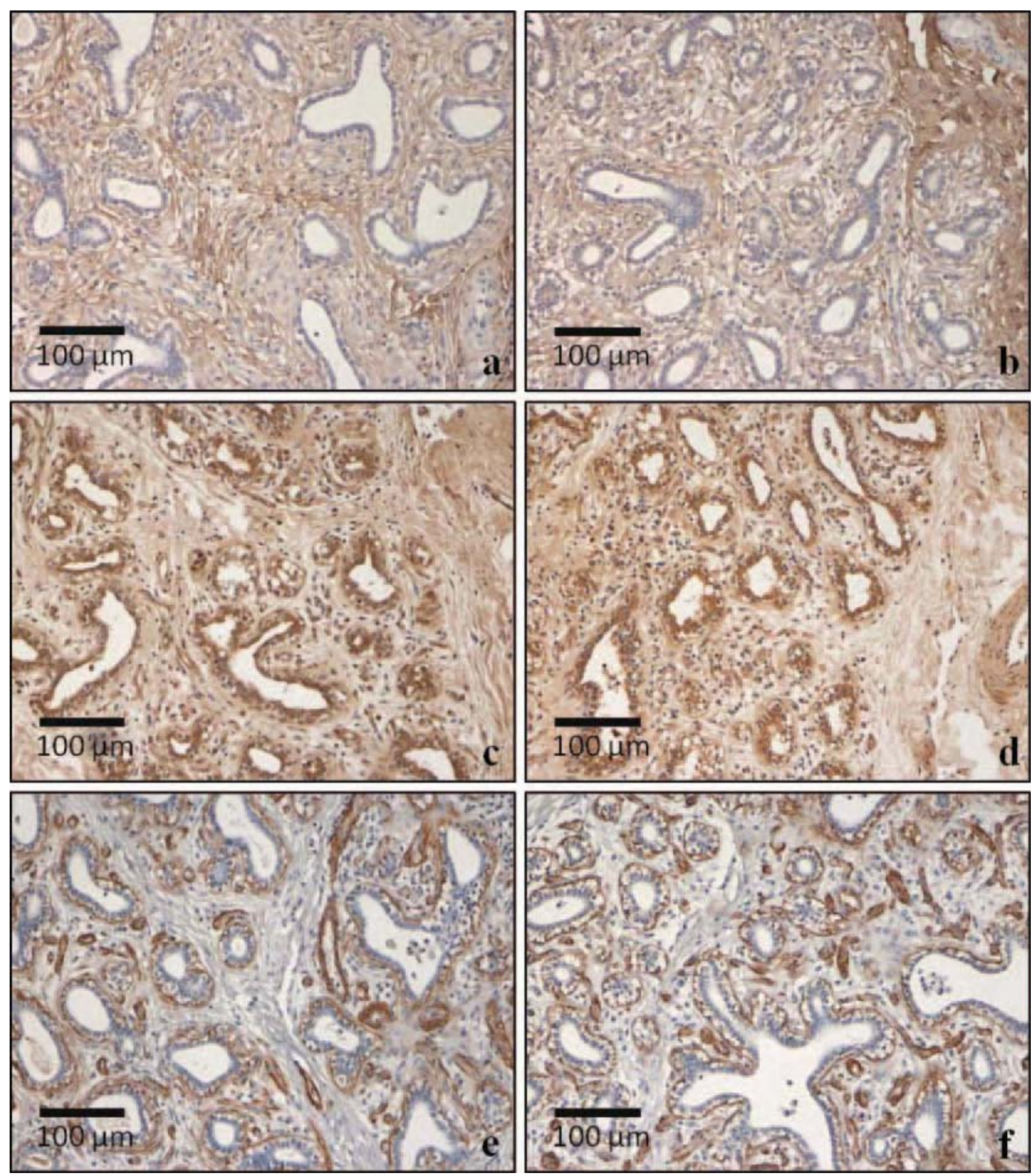

Figure 3. Immunohistochemical images $(200 \times)$ of bovine mammary tissue at 1 wk dry (1WD): (a) fibronectin staining with 0 ng of transforming growth factor- $\beta 1$ (TGF- $\beta 1) / \mathrm{mL}$; (b) fibronectin staining with $5 \mathrm{ng}$ of TGF- $\beta 1 / \mathrm{mL}$; (c) matrix metalloproteinase-3 (MMP-3) staining with $0 \mathrm{ng}$ of TGF- $\beta 1 / \mathrm{mL}$; (d) MMP-3 staining with $5 \mathrm{ng}$ of TGF- $\beta 1 / \mathrm{mL}$; (e) smooth muscle $\alpha$-actin (SMA) staining with 0 ng of TGF- $\beta 1 / \mathrm{mL}$; and (f) SMA staining with $5 \mathrm{ng}$ of TGF- $\beta 1 / \mathrm{mL}$.

As in our previous study, we found that percentage area of intralobular stroma expressing FN protein did not change with stage at biopsy (De Vries et al., 2010); however, percentage area of epithelial tissue expressing $\mathrm{FN}$, which included the basement membrane, did vary with stage at biopsy. Capuco et al. (1997) found that hydroxyproline, a marker of collagen synthesis, was greatest during mammogenesis in the dry period of dairy cows, a time point approximately equivalent to the 3BEC time point in our study. These data sug- gest that the greater percentage of $\mathrm{FN}$ associated with the epithelium is due in part to changes in basement membrane composition rather than changes in tissue morphology; that is, polarization of epithelial cells and formation of lumen within alveolar structures. Treatment with TGF- $\beta 1$ did not affect percentage area of epithelium or intralobular stroma expressing FN. In rodents, exogenous TGF- $\beta 1$ applied directly to the gland in vivo inhibited epithelial cell division within hours but stimulated extracellular matrix synthesis over a longer 
Table 1. Effects of treatment with 0 or $5 \mathrm{ng} / \mathrm{mL}$ of transforming growth factor- $\beta 1$ on fibroblasts in the intralobular stroma

\begin{tabular}{|c|c|c|c|c|c|}
\hline \multirow[b]{2}{*}{ Item } & \multicolumn{2}{|c|}{$0 \mathrm{ng} / \mathrm{mL}$} & \multicolumn{2}{|c|}{$5 \mathrm{ng} / \mathrm{mL}$} & \multirow{2}{*}{$\begin{array}{c}\text { Tukey } \\
\text { adjusted } \\
P \text {-value }\end{array}$} \\
\hline & LSM & $\mathrm{SE}$ & LSM & $\mathrm{SE}$ & \\
\hline Stromal cells (cells $/ \mathrm{mm}^{2}$ ) & 2,274 & 152 & 2,193 & 153 & 0.46 \\
\hline Activated stromal cells (cells $/ \mathrm{mm}^{2}$ ) & 640 & 77 & 763 & 77 & $0.03^{*}$ \\
\hline Activated stromal cells (\%) & 22.0 & 2.6 & 26.1 & 2.6 & $0.06^{* *}$ \\
\hline \multicolumn{6}{|l|}{ Late lactation } \\
\hline Fibroblasts (cells $/ \mathrm{mm}^{2}$ ) & 2,236 & 200 & 2,424 & 200 & 0.97 \\
\hline Myofibroblasts (cells $/ \mathrm{mm}^{2}$ ) & 710 & 109 & 811 & 109 & 0.90 \\
\hline Myofibroblasts (\%) & 24 & 3.6 & 25 & 3.6 & 0.99 \\
\hline \multicolumn{6}{|l|}{1 wk dry } \\
\hline Fibroblasts (cells $/ \mathrm{mm}^{2}$ ) & 2,670 & 200 & 2,374 & 200 & 0.78 \\
\hline Myofibroblasts (cells $/ \mathrm{mm}^{2}$ ) & 516 & 109 & 762 & 109 & 0.11 \\
\hline Myofibroblasts (\%) & 16 & 3.6 & 25 & 3.6 & 0.18 \\
\hline \multicolumn{6}{|l|}{3 wk before expected calving } \\
\hline Fibroblasts (cells $/ \mathrm{mm}^{2}$ ) & 2,221 & 212 & 1,879 & 212 & 0.73 \\
\hline Myofibroblasts (cells $/ \mathrm{mm}^{2}$ ) & 589 & 115 & 695 & 116 & 0.91 \\
\hline Myofibroblasts (\%) & 21 & 3.8 & 27 & 3.8 & 0.72 \\
\hline \multicolumn{6}{|l|}{1 wk before expected calving } \\
\hline Fibroblasts (cells $\left./ \mathrm{mm}^{2}\right)$ & 1,968 & 212 & 2,096 & 226 & 0.99 \\
\hline Myofibroblasts (cells $/ \mathrm{mm}^{2}$ ) & 744 & 116 & 782 & 121 & 0.99 \\
\hline Myofibroblasts (\%) & 27 & 3.8 & 28 & 4.0 & 1.0 \\
\hline
\end{tabular}

${ }^{*} P<0.05 ;{ }^{* *} 0.05<P<0.1$ (tendency).

time course (Daniel et al., 1996). The 2-h incubation with TGF- $\beta 1$ used in the current study may not have been sufficient to observe differences in $\mathrm{FN}$ synthesis in the stroma. Ignotz et al. (1986) observed a difference in ECM FN synthesis by embryonic chick fibroblasts only after $4 \mathrm{~h}$ of culture with TGF- $\beta 1$. Similarly, human fibroblasts cultured with $2 \mathrm{ng}$ of TGF- $\beta 1 / \mathrm{mL}$ did not show increases in FN synthesis until after $6 \mathrm{~h}$ in culture (Thannickal et al., 2000). Thus, the lack of a treatment effect on percentage FN may be due to the relatively

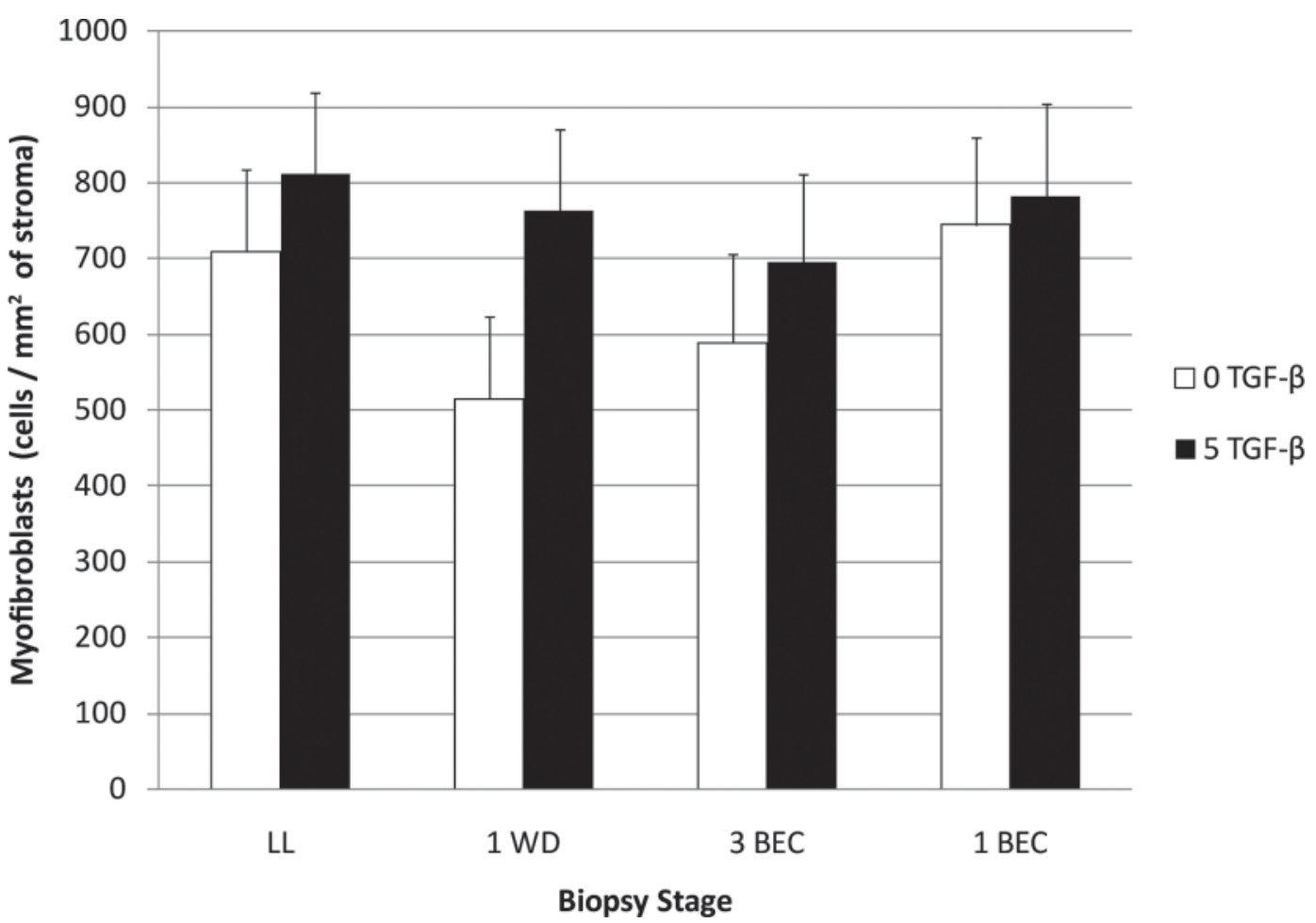

Figure 4. Effect of transforming growth factor- $\beta 1$ (TGF- 31 ) on the number of myofibroblasts as determined by number of cells per intralobular stromal area expressing smooth muscle $\alpha$-actin. Overall treatment effect at $P<0.05$. LL $=$ late lactation; $1 \mathrm{WD}=1 \mathrm{wk}$ dry; $3 \mathrm{BEC}=3$ wk before expected calving; and $1 \mathrm{BEC}=1 \mathrm{wk}$ before expected calving. 


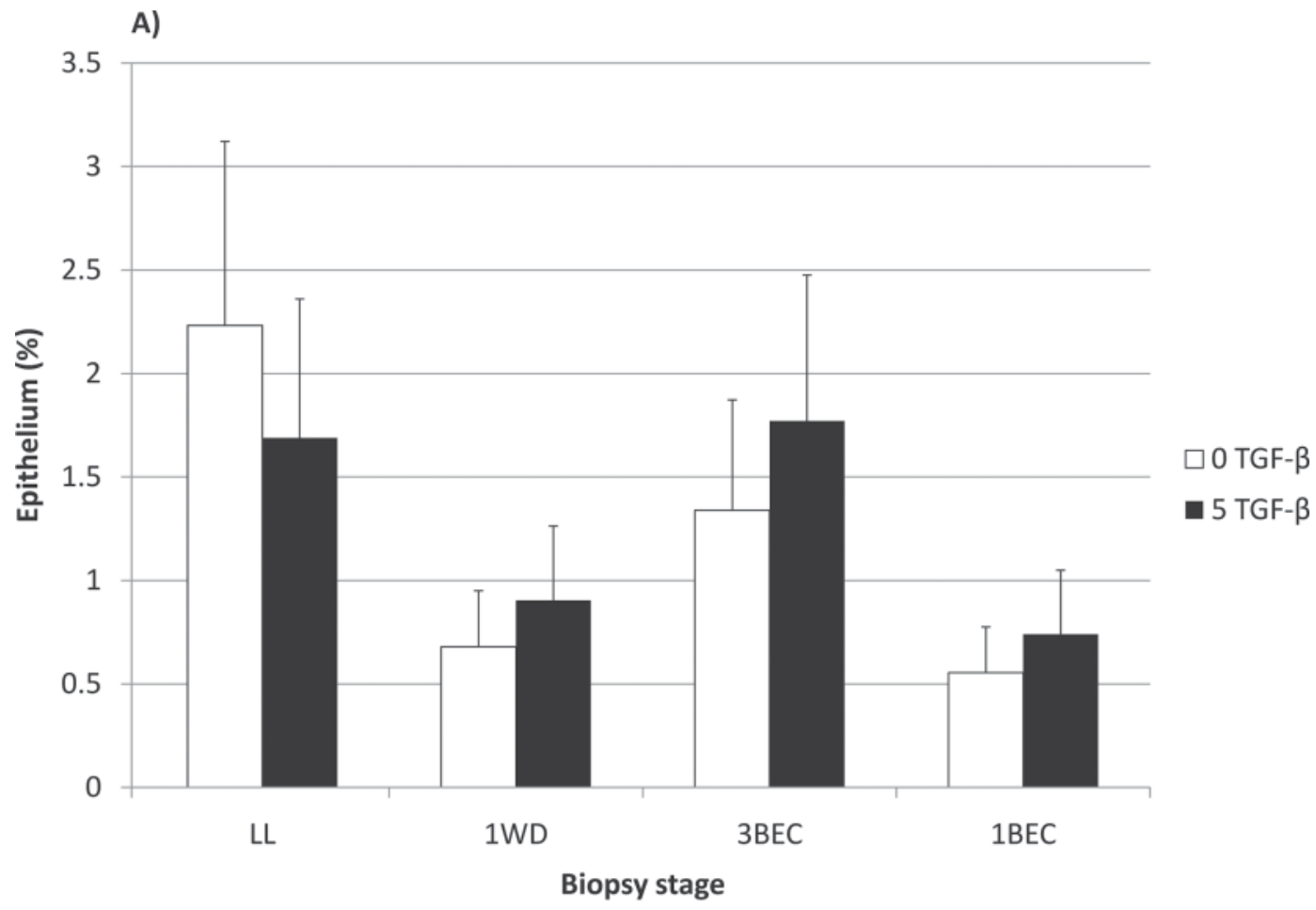

B)

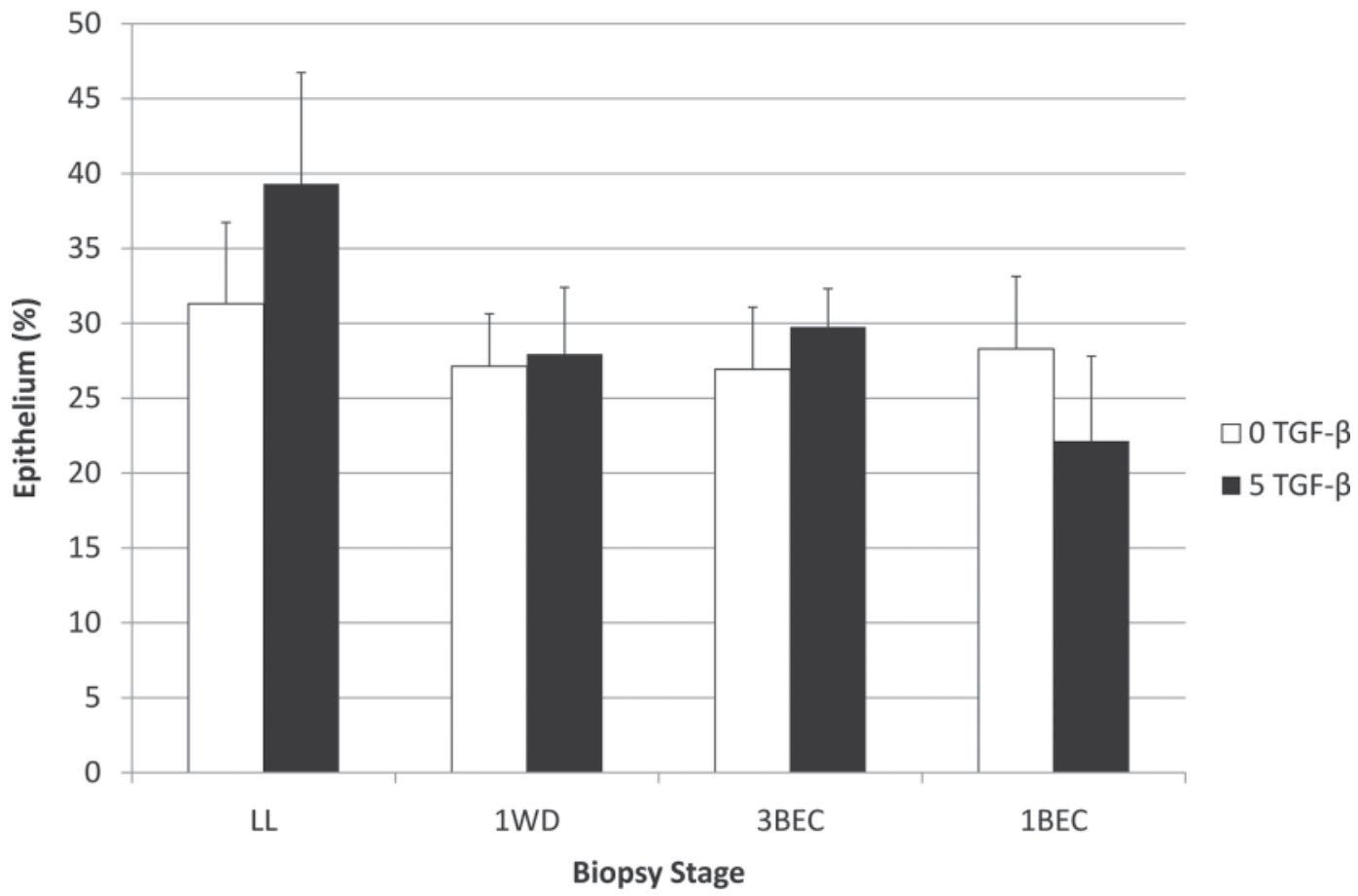

Figure 5. Mean percentage area of (A) fibronectin (FN) expression (overall effect of stage at biopsy; $P<0.05)$ and $(\mathrm{B})$ matrix metalloproteinase-3 (MMP-3) expression (overall effect of stage at biopsy: $P<0.05$ ) in epithelial tissue treated with 0 or $5 \mathrm{ng} / \mathrm{mL}$ transforming growth factor- $\beta 1$ (TGF- $\beta 1) . \mathrm{LL}=$ late lactation; $1 \mathrm{WD}=1 \mathrm{wk}$ dry; $3 \mathrm{BEC}=3 \mathrm{wk}$ before expected calving; and $1 \mathrm{BEC}=1 \mathrm{wk}$ before expected calving.

short incubation period and further investigations are needed to determine the longer term effects of TGF- $\beta 1$ treatment on ECM composition.
Although TGF- $\beta 1$ treatment had no effect on the expression of MMP-3 in intralobular stroma or epithelial tissue, stage at biopsy had a significant effect 
on MMP-3 expression. Expression of MMP-3 was significantly higher in tissues from LL cows than from those at 1BEC. Our previous studies showed that the tissue structure of LL samples was heterogeneous, with both secretory structures and collapsed alveoli present within same tissue sections (De Vries et al., 2010). Further, TGF- $\beta 1$ expression was greater in LL biopsies compared with biopsies taken during the dry period (De Vries et al., 2010), and these findings suggest that areas of the gland had already begun to involute when biopsies were taken at LL. The finding in the present study that higher levels of MMP-3 were expressed in epithelial tissue expression of samples taken at LL supports this conclusion.

Based on our results, TGF- $\beta 1$ induced changes in stromal cell activation and percentage of epithelial and fibroblast proliferation. Increasing the incubation time of explant culture may have allowed time for detection of TGF- $\beta 1$ effects on fibroblast cell density or FN and MMP-3 expression. Effects of TGF- $\beta 1$ treatment were most apparent in cultures from biopsies taken at 1WD, indicating that the first week of the dry period may be an ideal target for testing the efficacy of in vivo TGF- $\beta 1$ treatments to hasten mammary modeling to shorten the dry period and maximize milk production in the subsequent lactation.

\section{CONCLUSIONS}

Transforming growth factor- $\beta 1$ may mediate remodeling in vivo during the dry period of dairy cows. Short-term TGF- $\beta 1$ treatment of bovine mammary tissue increased the number of activated fibroblasts and increased the proliferation index of epithelial and fibroblast cells. Although changes in FN and MMP-3 were not detected in this study, further studies with longer incubation times or using in vivo implants are necessary to understand the potential for TGF- $\beta 1$. Transforming growth factor- $\beta 1$ has a potent effect on epithelial and stromal proliferation and composition. We believe that TGF- $\beta 1$ may affect mammary remodeling during the dry period of lactating dairy cows.

\section{REFERENCES}

Annen, E. L., A. C. Fitzgerald, P. C. Gentry, M. A. McGuire, A. V. Capuco, L. H. Baumgard, and R. J. Collier. 2007. Effect of continuous milking and bovine somatotropin supplementation on mammary epithelial cell turnover. J. Dairy Sci. 90:165-183.

Bierie, B., A. E. Gorska, D. G. Stover, and H. L. Moses. 2009. TGFbeta promotes cell death and suppresses lactation during the second stage of mammary involution. J. Cell. Physiol. 219:57-68.

Capuco, A. V., R. M. Akers, and J. J. Smith. 1997. Mammary growth in Holstein cows during the dry period: Quantification of nucleic acids and histology. J. Dairy Sci. 80:477-487.

Casey, T., T. Mulvey, T. Patnode, A. Dean, E. I. Zakrzewska, and K. I. Plaut. 2007. Mammary epithelial cells treated concurrently with the transforming growth factors-alpha (TGF- $\alpha$ ) and -beta (TGF- $\beta$ ) exhibit high rates of cell proliferation and cell death. Exp. Biol. Med. 232:1027-1040.

Daniel, C. W., S. Robinson, and G. B. Silberstein. 1996. The role of TGF-beta in patterning and growth of the mammary ductal tree. J. Mammary Gland Biol. Neoplasia 1:331-341.

Desmoulière, A., A. Geinoz, F. Gabbiani, and G. Gabbiani. 1993. Transforming growth factor-beta 1 induces alpha-smooth muscle actin expression in granulation tissue myofibroblasts and in quiescent and growing cultured fibroblasts. J. Cell Biol. 122:103-111.

De Vries, L. D., H. Dover, T. Casey, M. VandeHaar, and K. Plaut. 2010. Characterization of mammary stromal remodeling during the dry period. J. Dairy Sci. 93:2433-2443.

Dickson, S. R., and M. J. Warburton. 1992. Enhanced synthesis of gelatinase and stromelysin by myoepithelial cells during involution of the rat mammary gland. J. Histochem. Cytochem. 40:697-703.

Ellis, S., S. Purup, K. Sejrsen, and R. M. Akers. 2000. Growth and morphogenesis of epithelial cell organoids from peripheral and medial mammary parenchyma of prepubertal heifers. J. Dairy Sci. 83:952-961.

Farr, V. C., K. Stelwagen, L. Crate, A. Molenaar, T. McFadden, and S. Davis. 1996. An improved method for the routine biopsy of bovine mammary tissue. J. Dairy Sci. 79:543-549.

Farrelly, N., Y. J. Lee, J. Oliver, C. Dive, and C. H. Streuli. 1999. Extracellular matrix regulates apoptosis in mammary epithelial through a control on insulin signaling. J. Cell Biol. 144:13371347.

Faure, E., N. Heisterkamp, J. Groffen, and V. Kaartinen. 2000. Differential expression of TGF-beta isoforms during postlactational mammary gland involution. Cell Tissue Res. 300:89-95.

Gorska, A. E., R. A. Jensen, Y. Shyr, M. E. Aakre, N. A. Bhowmick, and H. L. Moses. 2003. Transgenic mice expressing a dominantnegative mutant type II transforming growth factor-beta receptor exhibit impaired mammary development and enhanced mammary tumor formation. Am. J. Pathol. 163:1539-1549.

Grinnell, F. 1994. Fibroblasts, myofibroblasts, and wound contraction. J. Cell Biol. 124:401-404.

Holland, M. S., J. A. Stasko, and R. E. Holland. 2007. Influence of extracellular matrix on bovine mammary gland progenitor cell growth and differentiation. Am. J. Vet. Res. 68:476-482.

Hurley, W. L. 1989. Symposium: Mammary gland function during involution and the declining phase of lactation. J. Dairy Sci. 72:1637-1646.

Ignotz, R. A., B. Kelly, R. J. Davis, and J. Massagué. 1986. Biologically active precursor for transforming growth factor type alpha, released by retrovirally transformed cells. Proc. Natl. Acad. Sci. USA 83:6307-6311.

Jhappan, C., A. G. Geiser, E. C. Kordon, D. Bagheri, L. Hennighausen, A. B. Roberts, G. H. Smith, and G. Merlino. 1993. Targeting expression of a transforming growth factor beta 1 transgene to the pregnant mammary gland inhibits alveolar development and lactation. EMBO J. 12:1835-1845.

Joseph, H., A. E. Gorska, P. Sohn, H. L. Moses, and R. Serra. 1999. Overexpression of a kinase-deficient transforming growth factor- $\beta$ type II receptor in mouse mammary stroma results in increased epithelial branching. Mol. Biol. Cell 10:1221-1234.

Kingsley, D. M. 1994. The TGF- $\beta$ superfamily: New members, new receptors, and new genetic tests of function in different organisms. Genes Dev. 8:133-146.

Musters, S., K. Coughlan, T. McFadden, R. Maple, T. Mulvey, and K. Plaut. 2004. Exogenous TGF-beta1 promotes stromal development in the heifer mammary gland. J. Dairy Sci. 87:896-904.

Noel, A., and J.-M. Foidart. 1998. The role of stroma in breast carcinoma growth in vivo. J. Mammary Gland Biol. Neoplasia 3:215225.

Nørgaard, J. V., P. K. Theil, M. T. Sorensen, and K. Sejrsen. 2008. Cellular mechanisms in regulating mammary cell turnover during lactation and dry period in dairy cows. J. Dairy Sci. 91:23192327.

Petrov, V. V., R. H. Fagard, and P. J. Lijnen. 2002. Stimulation of collagen production by transforming growth factor-beta 1 during 
differentiation of cardiac fibroblasts to myofibroblasts. Hypertension 39:258-263.

Pierce, D. F., Jr., M. D. Johnson, Y. Matsui, S. D. Robinson, L. I. Gold, A. F. Purchio, C. W. Daniel, B. L. Hogan, and H. L. Moses. 1993. Inhibition of mammary duct development but not alveolar outgrowth during pregnancy in transgenic mice expressing active TGF-beta 1. Genes Dev. 7(12A):2308-2317.

Plath, A., R. Einspanier, F. Peters, F. Sinowatz, and D. Schams. 1997. Expression of transforming growth factor alpha and beta- 1 messenger RNA in the bovine mammary gland during during different stages of development and lactation. J. Endocrinol. 155:501-511.

Plaut, K., A. Dean, T. Patnode, and T. Casey. 2003. Effect of transforming growth factor-beta (TGF- $\beta$ ) on mammary development. J. Dairy Sci. 86(E. Suppl.):E16-E27.

Rastani, R. R., R. R. Grummer, S. J. Bertics, A. Gumen, M. C. Wiltbank, D. G. Mashek, and M. C. Schwab. 2005. Reducing dry period length to simplify feeding transition cows: Milk production, energy balance, and metabolic profiles. J. Dairy Sci. 88:1004-1014.

Rønnov-Jessen, L., and O. W. Petersen. 1993. Induction of alphasmooth muscle actin by transforming growth factor-beta 1 in quiescent human breast gland fibroblasts. Implications for myofibroblast generation in breast neoplasia. Lab. Invest. 68:696-707.

Silberstein, G. B., P. Strickland, S. Coleman, and C. W. Daniel. 1990. Epithelium-dependent extracellular matrix synthesis in transforming growth factor $\beta 1$ growth inhibited mouse mammary gland. J. Cell Biol. 110:2209-2219.
Silberstein, G. B., and C. W. Daniel. 1987. Reversible inhibition of mammary gland growth by transforming growth factor $\beta$. Science 237:291-293.

Silberstein, G. B., K. C. Flanders, A. B. Roberts, and C. W. Daniel. 1992. Regulation of mammary morphogenesis: Evidence for extracellular matrix-mediated inhibition of ductal budding by transforming growth factor- 31 . Dev. Biol. 152:354-362.

Simian, M., Y. Hirai, M. Navre, Z. Werb, A. Lochter, and M. J. Bissell. 2001. The interplay of matrix metalloproteinases, morphogens and growth factors is necessary for branching of mammary epithelial cells. Development 128:3117-3131.

Sorensen, M. T., J. V. Norgaard, P. K. Theil, M. Vestergaard, and K. Sejrsen. 2006. Cell turnover and activity in mammary tissue during lactation and the dry period in dairy cows. J. Dairy Sci 89:4632-4639.

Talhouk, R. S., M. J. Bissell, and Z. Werb. 1992. Coordinated expression of extracellular matrix-degrading proteinases and their inhibitors regulates mammary epithelial function during involution. J. Cell Biol. 118:1271-1282.

Thannickal, V. J., R. Day, S. G. Klinz, M. C. Bastien, J. M. Larios, and B. L. Fanburg. 2000. Ras-dependent and -independent regulation of reactive oxygen species by mitogenic growth factors and TGF-beta1. FASEB J. 14:1741-1748. 